\title{
Analyzing the market position of fish species subject to the impact of long-term changes: a case study of French fisheries in the Bay of Biscay
}

\author{
Pascal Le Floc'h ${ }^{1, a}$, Jean-Charles Poulard ${ }^{2}$, Olivier Thébaud ${ }^{3}$, Fabian Blanchard ${ }^{4}$, Julien Bihel ${ }^{1}$ \\ and Fabien Steinmetz ${ }^{3}$ \\ 1 Université de Bretagne Occidentale, UMR-Amure, 2 rue de l'Université, 29334 Quimper Cedex, France \\ 2 Ifremer, Ecologie et Modèles pour l'Halieutique (EMH), BP 21105, 44311 Nantes Cedex 3, France \\ 3 Ifremer, UMR-Amure, Centre de Brest, BP 70, 29280 Plouzané, France \\ ${ }^{4}$ Ifremer, Dép. Halieutique Méditerranéenne et Tropicale, BP 477, 97331 Cayenne, Guyane française
}

Received 14 September 2007; Accepted 21 March 2008

\begin{abstract}
Market position and its evolution were analysed in nine key fish and cephalopod species subject to longterm changes, using the Bay of Biscay fisheries as a case study. Although such long term changes have already been documented, and in some cases shown to be related to the impacts of fishing, changes in the physical environment, or both, relatively little work has been devoted to their potential consequences in economic terms. The nature and extent of these consequences was determined in the present study by looking at the composition of the affected fish production, and the status of different fish products on the markets. We propose a methodology to characterize market position for this set of nine species. The selected species represent a significant part of the gross turnover of French fishing fleets operating in the bay. These species were characterized in terms of their potential sensitivity to fishing and changes in environmental conditions due to global warming. We separated species potentially positively (Engraulis encrasicolus and Lophius budegassa) and negatively affected (Pollachius pollachius and Lophius piscatorius) by warming. Evolution of the value of production of the nine species was then depicted using analysis of macro-economic index (production and potential consumption) and price indices. This revealed the relatively high sensitivity of domestic production to the market crisis that occurred in France in the early 1990s, compared to imported and exported products. The relative position of individual species, with respect to the market and its evolution between 1990 and 2005, was analyzed by multi-factorial analysis. Results derived from the analysis clearly distinguish two groups of species, the first characterized by higher prices (monkfish, Nephrops, sole, seabass) and the second by larger volumes available on the French market (pollack, hake, anchovy, sardine, cuttlefish). We conclude that a major part (69 to 87\%) of the gross turnover associated with catches of these fish species in the Bay of Biscay remains potentially unaffected by long-term changes related to climate.
\end{abstract}

Key words: Environmental change / Macro-economic aggregates / Fish market / Atlantic Ocean

Résumé - Suivi de la situation commerciale d'espèces marines sujettes au changement de long terme dans la communauté de poissons : cas des pêcheries du golfe de Gascogne. La situation commerciale de neuf espèces-clés, poissons et céphalopode, et leur évolution sont étudiées tenant compte des changements de long terme dans les communautés de poissons, en prenant comme cas d'étude les pêcheries du golfe de Gascogne. Si l'analyse des changements de long terme est bien renseignée, tant du point de vue de l'impact de la pêche que des modifications dans l'environnement physique, il existe peu d'études sur les effets économiques des espèces exploitées. La nature et l'étendue de ces effets sont déterminées par la composition spécifique de la production halieutique considérée, et par le statut des espèces pêchées sur les marchés. Nous proposons une méthode pour caractériser ce statut de ces neuf espèces commerciales. Les espèces sélectionnées contribuent significativement au chiffre d'affaire des flottilles françaises situées dans le golfe de Gascogne. Elles sont caractérisées selon leur sensibilité potentielle à l'impact de la pêche et aux variations des conditions environnementales, dont le changement climatique. Nous distinguons les espèces potentiellement moins vulnérables (Engraulis encrasicolus et Lophius budegassa) de celles potentiellement plus sensibles (Pollachius pollachius et Lophius piscatorius) aux effets du réchauffement climatique. L'évolution de la valeur de débarquement de

\footnotetext{
${ }^{a}$ Corresponding author: plefloch@univ-brest.fr
} 
ces neuf espèces est décrite à partir de l'analyse d'indicateurs macro-économiques (production et consommation apparente) et des indices de prix. On démontre ainsi la plus grande sensibilité de la production domestique pendant la crise de la pêche en France (1992-1994), par rapport à la production étrangère ou destinée aux marchés étrangers. La situation commerciale des espèces et son évolution temporelle est analysée sur la période 1990-2005 à partir d'une analyse multi-factorielle. Les résultats de cette analyse identifient clairement deux groupes de produits, dont l'un est marqué par des prix stables et élevés sur la période d'étude (baudroie, langoustine, sole, bar) et le second caractérisé par des prix plus bas et soumis aux effets de substitution entre espèces (lieu jaune, merlu, anchois, sardine, seiche). Il ressort de l'analyse que la majeure partie du chiffre d'affaire (69 à $87 \%$ ), de la production de ces neuf espèces du golfe de Gascogne, est peu affectée par les changements de long terme.

\section{Introduction}

Long-term changes in marine fish communities are now well documented. Applied research devoted to the description and explanation of these modifications has shown that such changes can result both from the impacts of fishing, and/or changes in the physical environment. In particular, the decreasing trend in the mean trophic level of landings from world fisheries has been described as a consequence of the so-called "fishing down marine food webs" phenomenon (Pauly et al. 1998). Such trends have also been observed at a regional level and at the scale of the fisheries exploited by French fleets in the North East Atlantic (Steinmetz et al. 2006). Beyond the impacts of fishing, changes in the physical environment of fish communities are also considered to be a major source of perturbation, which may contribute to explaining changes observed in the relative abundance of fish species at local to regional scales. An example of an area presently under study is the Arctic region. The eight countries bordering this area are cooperating through an intergovernmental council to assess the impact of climate change on fisheries (Schrank 2007). The Arctic Climate Impact Assessment (ACIA) has shown that effects from climate change interact with effects of fishing to explain changes in fish communities and fishery production. Similar results have been obtained in studies of the Bay of Biscay shelf ecosystem. In this region, warming of surface waters, with an increase of up to $0.6^{\circ} \mathrm{C}$ per decade from 1971 to 1998 , has been observed (Planque et al. 2003; Koutsikopoulos et al. 1998; Désaunay et al. 2006), as well as an increase in sea bottom temperature (Blanchard and Vandermeirsch 2005). These changes have been shown to contribute to modifications in the fish community of this ecosystem (Blanchard and Vandermeirsch 2005; Poulard and Blanchard 2005; Désaunay et al. 2006).

While a growing number of fisheries research programs focus on these issues (Stenevik and Sundby 2007; Castro-Ortiz and Luch-Belda 2007), relatively little work has been done to address to potential economic consequences of fishing pressure and changes in the physical environment (Pinnegar et al. 2002; Steinmetz et al. 2006). The nature and extent of these consequences, particularly for local fisheries, will be determined by the resulting composition of the fish production, and by the status of fish products on the markets. Recent analysis of trends in the composition of landings by French fleets operating in the Bay of Biscay shows that the proportion of high-valued fish species has tended to decrease in the total volumes landed, to the benefit of lower-value species (Steinmetz et al. 2008; Thébaud et al. 2008). The economic implications of such changes depend on the potential responses of prices to variations in volumes landed, which may differ between species. A standard assumption in economics is that highervalued products, with limited substitutes, display less priceflexibility than lower-valued products, with many substitutes (Samuelson and Nordhaus 2001). Hence, an assessment of the potential economic impacts of global changes affecting fish resources requires an evaluation of the market position of the species considered.

In this paper we propose a methodology to characterize this market position, based on the case of the production of French fisheries in the Bay of Biscay. The analysis is based on a selection of nine fish species landed by fishing fleets over the 19902005 period, representing a significant proportion of the gross turnover of French fishing fleets operating in the Bay. These species were first characterized in terms of their potential sensitivity to fishing and changes in environmental conditions due to global warming. Evolution of the production value of the nine species was then depicted using index analysis. This allowed us to show the relatively high sensitivity of domestic production to the market crisis that occurred in France in the early 1990s. Evolution of total resources of the nine species on the French market was then analyzed, putting emphasis on the part of production derived from the Bay of Biscay in the total resources/uses. The relative position of individual species with respect to the market and its evolution through time was analyzed via multi-factorial analysis. Based on this characterization of the position of each species on the French market, we discuss the economic implications of potential changes in the abundance of these nine species in the Bay of Biscay due to global warming.

\section{Materials and methods}

\subsection{Species}

Analysing the position of key species under long-term changes in marine fish communities implies describing the market structure of fish commodities in terms of domestic production, imports and exports. It was not possible for this study to include all commercial species exploited in the Bay of Biscay, particularly because different nomenclatures are used for species in production databases (ICES, FAO) and foreign trade statistics (EUROSTAT). Hence, a selection of nine major commercial species was made (Table 1), representing a significant proportion of the gross turnover for several segments of the French fleets. Two species considered in the analysis are pelagic: anchovy and sardine; four are demersal: cuttlefish, seabass, pollock, and hake; and the last three are 
Table 1. List of the nine selected species, and the coverage rate of their potential consumption by Bay of Biscay production during the 1990-2005 period.

\begin{tabular}{llrr}
\hline \multirow{2}{*}{ Common name } & Species & \multicolumn{2}{c}{$\%$} \\
\cline { 3 - 4 } & & Min & Max \\
\hline Anchovy & Engraulis encrasicolus & 9 & 266 \\
Cuttlefish & Sepia officinalis & 30 & 114 \\
Hake & Merluccius merluccius & 6 & 20 \\
Monkfish & Lophius piscatorius and L. & 14 & 26 \\
& budegassa & & \\
Nephrops & Nephrops norvegicus & 18 & 35 \\
Pollack & Pollachius pollachius & 1 & 4 \\
Sardine & Sardina pilchardus & 16 & 28 \\
Seabass & Dicentrarchus labrax & 55 & 80 \\
Sole & Solea solea & 29 & 58 \\
\hline
\end{tabular}

benthic: Nephrops norvegicus, sole and monkfish (commercially speaking, monkfish is one product, although it includes two different species from a taxonomic point of view Lophius piscatorius and L. budegassa).

Information on catches and landings of the nine species was obtained from the ICES database of official landings per species per area by member states (http://www.ices.dk), and from the French Marine Fisheries and Aquaculture Directorate. Landings data were extracted from ICES statistical records in terms of volume (tons), selecting production for areas VIII a-e, except for the year 1999 (for which no information was sent to ICES by the French Authorities). In this case, we used production data for the French Atlantic coast published by the National Office for Sea and Aquaculture Products (Office National Interprofessionnel des Produits de la Mer et de l'Aquaculture).

Based on these statistics, the degree to which the selected species are representative can be assessed in terms of their contribution to total landings by fleets operating in the bay. Between 1990 and 2005, annual landings of the two pelagic species (anchovy and sardine) represented 39\% to 78\% of total annual landings of pelagic species by French fleets operating in the Bay of Biscay fisheries. Landings of the four demersal species (cuttlefish, seabass, pollock, and hake) represented between $48 \%$ and $68 \%$ of total landings by these fleets, while landings of monkfish, Nephrops and sole represented between $52 \%$ and $75 \%$ of their total benthic production. Taken together, the production of the selected species represented at least $52 \%$ of total French landings from the Bay of Biscay between 1990 and 2005.

\subsubsection{Commercial data}

As the ICES database focuses on catch statistics, no economic information was available from this source to analyse trends in the value of production by fishing area. Consequently, average annual ex-vessel prices per species recorded in the national statistical reports for landings in French Atlantic fishing harbours (from Douarnenez to Hendaye) were used to assess the value of landings per species. All prices were deflated to 2005 prices using the French retail price index (http://www.insee.fr).

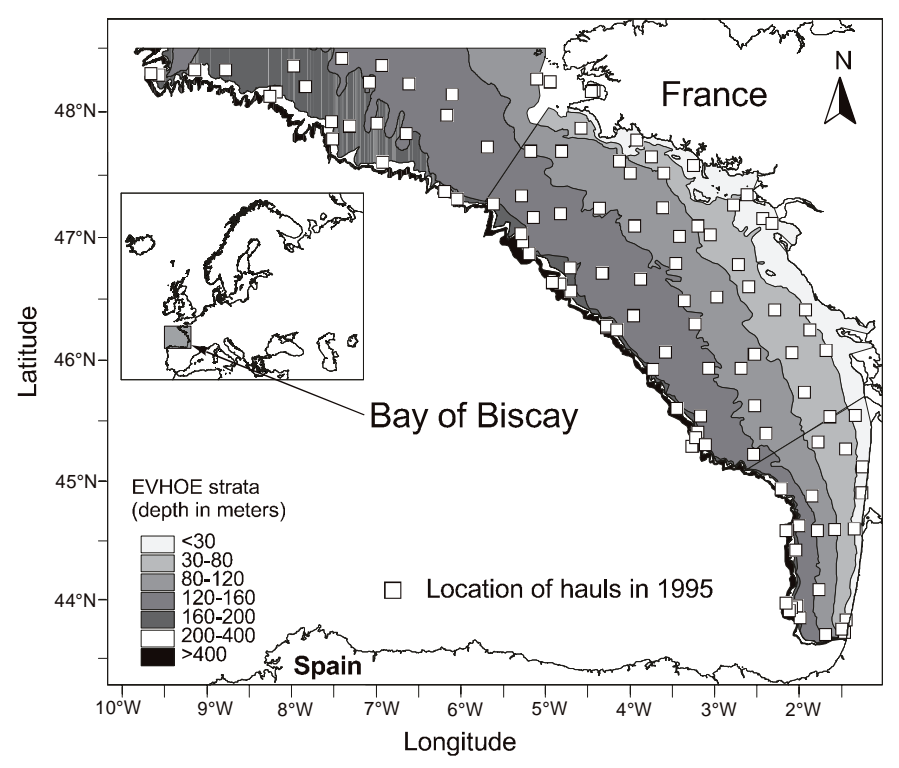

Fig. 1. Area of the eastern continental shelf of the Bay of Biscay studied during the 17 groundfish surveys carried out by IFREMER from September to December of the years 1987 to 1990, 1992, 1994, 1995 and from 1997 to 2006.

Data on foreign trade was obtained from Eurostat databases. Statistics on both annual volumes and values of imports and exports of the selected fish species were extracted for the period 1990-2005. Given that data collection and processing on imports and exports do not mention scientific species names, some aggregation of different species occurs in the trade databases. There is no straightforward approach to establishing the relative proportions of the different species included in measurements of trade flows of commonly named products: e.g. statistics for pollack include trade for Alaskan and European Pollack, and trade flows for hake include trade for European, Patagonian and South-African hake. Tests were carried out to assess the effects of excluding trade data for these species from the multi-variate analysis of the market position of individual species (see below). As no determinant impact was observed on the results, we decided to keep this information in the analysis.

\subsubsection{Survey data}

Biogeographic characteristics and temporal evolution of the abundance, assessed through groundfish surveys, were associated with the economic information in order to analyse the relationships between market position and biological status of the selected fish species, particularly in terms of their potential vulnerability to climate change.

Data used in the analysis was collected during 17 annual groundfish surveys carried out by IFREMER between October and December from 1987 to 2006 (EVHOE series, which has gaps in 1991, 1993 and 1996), on the eastern continental shelf of the Bay of Biscay (Poulard and Blanchard 2005; Woillez et al. 2007). The study area is located between $43^{\circ} 30^{\prime} \mathrm{N}$ and $48^{\circ} 30^{\prime} \mathrm{N}$ and its depth ranges from 15 to $600 \mathrm{~m}$ (Fig. 1). The sampling design was stratified according to latitude and depth. 
Table 2. Biogeographic characteristics (mean latitude, latitudinal range) and species categories for the nine selected species (adapted from Poulard and Blanchard 2005).

\begin{tabular}{|c|c|c|c|c|}
\hline \multirow{2}{*}{\multicolumn{2}{|c|}{\begin{tabular}{l}
\multicolumn{1}{c}{ Mean latitude } \\
(in degrees of latitude) \\
Category
\end{tabular}}} & \multicolumn{3}{|c|}{$\begin{array}{c}\text { Species range } \\
\text { (in degrees of latitude) }\end{array}$} \\
\hline & & 1 & 2 & 3 \\
\hline & Limit & {$[20-40[$} & {$[40-67[$} & [67-127] \\
\hline 1 & {$[2.5-41[$} & & $\begin{array}{l}\text { Dicentrarchus labrax } \\
\text { Sardina pilchardus } \\
\text { Solea solea }\end{array}$ & $\begin{array}{c}\text { Engraulis encrasicolus } \\
\text { Lophius budegassa }\end{array}$ \\
\hline 2 & {$[41-53[$} & & $\begin{array}{l}\text { Merluccius merluccius } \\
\text { Nephrops norvegicus } \\
\text { Sepia officinalis }\end{array}$ & \\
\hline 3 & {$[53-60]$} & $\begin{array}{l}\text { Lophius piscatorius, } \\
\text { Pollachius pollachius }\end{array}$ & & \\
\hline
\end{tabular}

A 36/47 GOV trawl was used with a $20 \mathrm{~mm}$ mesh codend liner. Haul duration was $30 \mathrm{~min}$ at a towing speed of 4 knots. Fishing was mainly restricted to daylight hours. Catch weights and catch numbers were recorded for all species.

\subsection{Methods}

\subsubsection{Potential vulnerability of species to climate change}

A growing number of studies show that climate change may significantly impact marine fish communities (Poulard and Blanchard 2005; Perry et al. 2005; Hiddink and Terhofstede 2008). We characterized the species selected for our analysis in terms of their potential sensitivity to climate change, following the classification by Poulard and Blanchard (2005). Table 2 illustrates this classification: species can be ranked according to the combination of mean latitude and range (in degrees of latitude) of the area over which they are distributed. For instance, Lophius budegassa is ranked in the mean latitude class " 1 " and the species range class " 3 " (with Engraulis encrasicolus), while Lophius piscatorius belongs to the mean latitude class " 3 " and the species range class "1" (including Pollachius pollachius). The most Northern species (Lophiusp iscatorius and Pollachius pollachius) are characterized by the narrowest range. A potential index of sensitivity to climate change can be calculated as the difference between the mid-latitude of the species distribution range and the mid-latitude of the Bay of Biscay $\left(46^{\circ} 48^{\prime} \mathrm{N}\right)$, weighted by species latitudinal range. Interpretation of this index is based on the assumption that increased water temperature will induce a northwards shift in species moving from southern to northern latitudes.

\subsubsection{Macro-economic aggregates}

Economic flows were represented through macroeconomic aggregates computed according to the rules adopted by the European System of National Accounts (ESA95). Its major principles refer to a double accounting procedure (Temam 2000). Aggregates appearing on the right side of the accounts are considered as resources (output, $Y$; and imports, $M$ ), those included on the left side are the uses (intermediate and final consumption, $\mathrm{C}$; and exports, $\mathrm{X}$ ), such that $C+X=Y+M$. Goods available on the market are then equal to resources $(Y+M)$ or uses $(C+X)$. From this, the potential consumption $C=Y+M-X$ can be assessed. Here, potential consumption results from national landings adding imports and subtracting exports. All quantities included in the analysis were expressed in tons, converting all species in live weight equivalents based on transformation coefficients, which take into account the way in which traded fish are conditioned.

The Fisher price index was used to describe trends in Bay of Biscay production of the nine species, following Steinmetz et al. (2006). The Fisher price index $\left(F P_{t / 0}=\right.$ $\left.\sqrt{L P_{t / 0} \times P P_{t / 0}}\right)$ measures the rate of change in landing prices, taking into account the evolution of the structure of landings in volume. It is derived from the Laspeyres price in$\operatorname{dex}\left(L P_{t / 0}=\sum_{i}^{n} p_{i t} q_{i 0} \mid \sum_{i}^{n} p_{i 0} q_{i 0}\right)$ and the Paasche price index $\left(P P_{t / 0}=\sum_{i}^{n} p_{i t} q_{i t} \mid \sum_{i}^{n} p_{i 0} q_{i t}\right)$. We applied Fisher price index calculations at four levels: the fishery, French landings, exports and imports.

\subsubsection{Multivariate analysis}

Exploitation of the selected species in the Bay of Biscay was placed in the context of the French national market for fish, using a multi-table multivariate analysis called MultipleFactor Analysis (MFA). The dataset was comprised of 11 indicators (Table 3 ) for each year and each species (Table 1), related in volume to the fishery production $Y$, imports $M$, exports $X$ and potential consumption $C$ for consumers (final uses) and processing plants (intermediate uses). $M$ and $X$ were stated for two market segments: for fresh $\left(M_{\mathrm{fe}}, X_{\mathrm{fe}}\right)$ and frozen $\left(M_{\mathrm{fo}}, X_{\mathrm{fe}}\right)$ goods. Price variables were included for production, imports and exports.

The data were organised into a 3D multi-table structure, as a collection of yearly matrices (16 years). Each matrix had nine rows, each representing a species, and 11 columns representing the indicators describing the nine species. The tables were used to run a Multiple-Factor Analysis (MFA). MFA (Escofier and Pagès 1994; Poulard and Léauté 2002; Stanimirova et al. 
Table 3. List of the indicators used in the Multiple Factor Analysis (MFA) and summary of correlation between variables and the first three MFA factors. - correlation $<-0.5 ;+$ correlation $>0.5$. The numbers in parenthesis are the number of correlated years among the 16 considered in the study. Correlations are indicated only when the number of correlated years is $>9$ per variable.

\begin{tabular}{|c|c|c|}
\hline \multirow[t]{2}{*}{ Variable } & & Code Axis \\
\hline & & $\begin{array}{lll}1 & 2 & 3\end{array}$ \\
\hline Potential consumption & $C$ & $15+16+$ \\
\hline Landing price $(p)$ in the Bay of Biscay (bb) & $p_{\mathrm{Y}}$ & $16-$ \\
\hline Import price for fresh products & $p_{\mathrm{Mfe}}$ & $16-$ \\
\hline Import price for frozen products & $p_{\text {Mfo }}$ & $16-$ \\
\hline Export price for fresh products & $p_{\mathrm{Xfe}}$ & $16-$ \\
\hline Export price for frozen products & $p_{\mathrm{Xfo}}$ & $16-$ \\
\hline Landed quantities from the bay of Biscay & $Y$ & $14+10-9-$ \\
\hline Imported quantities for fresh products & $M_{\mathrm{fe}}$ & 14 \\
\hline Imported quantities for frozen products & $M_{\text {fo }}$ & $16+$ \\
\hline Exported quantities for fresh products & $X_{\mathrm{fe}}$ & $15-$ \\
\hline Exported quantities for frozen products & $X_{\text {fo }}$ & $11+$ \\
\hline
\end{tabular}

2005; Woillez et al. 2007) extends principal component analysis (PCA) methodology to the analysis of 3D structured data. In particular, MFA is appropriate to cases where the same variables (i.e. production and economic indicators in our data matrix columns) are measured for the same individuals (i.e. species in our data matrix rows) at different times (third dimension of the data structure, i.e. the 16 years of the studied period). This method allows a single factorial space to be constructed, in which the data matrix for each time step, variable and individual is represented. This unique factorial space is a compromise that best matches those of each data matrix at each time step. It allows extensive tables of data to be represented pictorially in such a way that groupings among variables in space and time can be readily identified.

The method proceeds in two steps. First, a PCA is performed on each data matrix. Then, each variable at each time step is weighted by the inverse of the first Eigenvalue of that matrix. A general matrix is constructed that contains all the weighted variables in columns and the individuals as rows. The PCA of this general matrix constructs the MFA compromise factorial plane. Its principal axes are interpreted using the correlation of the variables with the axes. The interest of this method is the construction of a compromise factorial space in which to represent the 3D structure of the data: each individual is represented by $n$ points ( $n$ repetitions in time) as well as by its gravity centre (average position in the compromise factorial space). In our case, results will show the mean position for each species, explained according to the nature of the markets to which products were supplied over the 1990-2005 period.

\section{Results}

\section{Potential sensitivity of the nine species to warming}

Table 2 presents the results of the sensitivity index that was computed. Based on the index, it appears that two species (Pollachius pollachius and Lophius piscatorius) could potentially be negatively affected by warming, while two species (Lophius
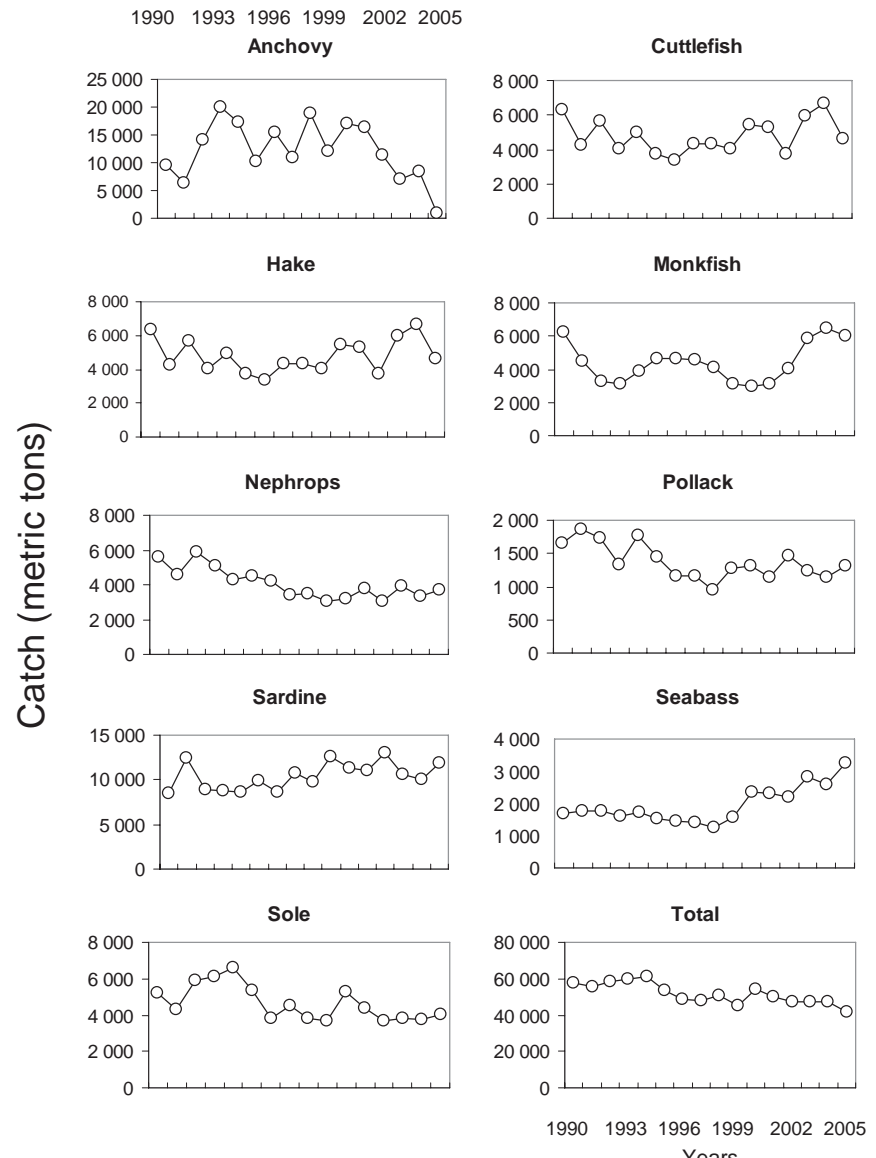

Years

Fig. 2. French landings (in metric tons) for the nine selected species from the Bay of Biscay between 1990 and 2005. Source: ICES (19901998, 2000-2005) and OFIMER (1999).

budegassa, Engraulis encrasicolus) could potentially be positively affected. For five of the nine species considered in this analysis, the potential impacts of warming would appear to be undetermined. Trends observed in the scientific surveys for the nine species are presented in Table 2 so as to provide information on the changes observed in the Bay of Biscay. These reflect modifications in the abundance and characteristics of fish populations resulting from a combination of factors, including fishing pressure and environmental changes. There is hence no direct link between these trends and the sensitivity index.

Production and apparent consumption of the nine species over the 1990-2005 period

Catches of the nine selected species declined overall during the study period (Fig. 2): from $58000 \mathrm{t}$ in 1990 to $42000 \mathrm{t}$ in 2005, with a peak of $62000 \mathrm{t}$ in 1994. The highest contributions were from anchovy, hake and sardine. Although output levels for the latter species remained constant over time, hake production dropped to $6000 \mathrm{t}$ from 1996 (a reduction of 50\% compared with its previous levels) and anchovy decreased dramatically over the last years of the study period.

Figures 2 and 3 illustrate the evolution of French landings from the Bay of Biscay and potential consumption of the nine 
199019931996199920022005 Anchovy

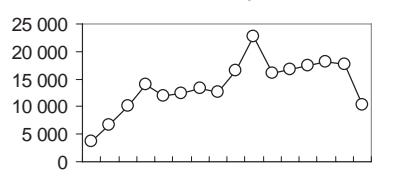

Hake
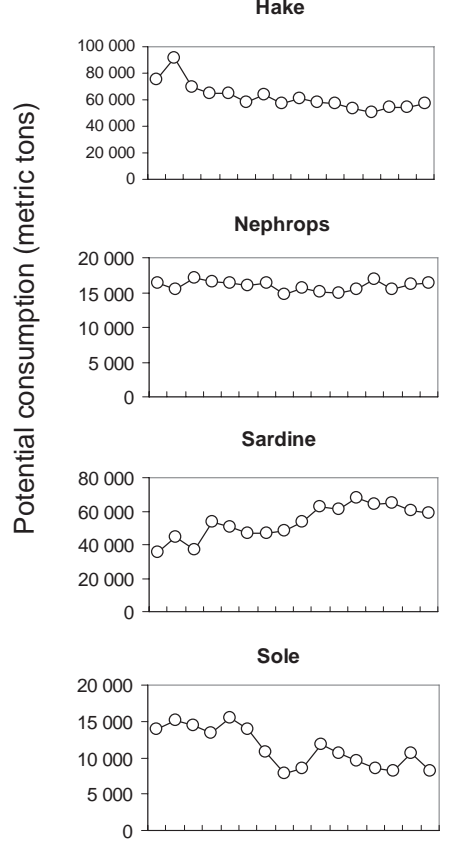

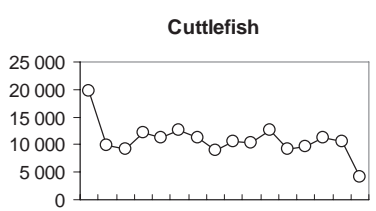

Monkfish
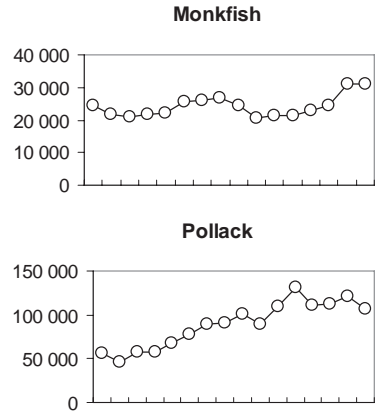

Seabass
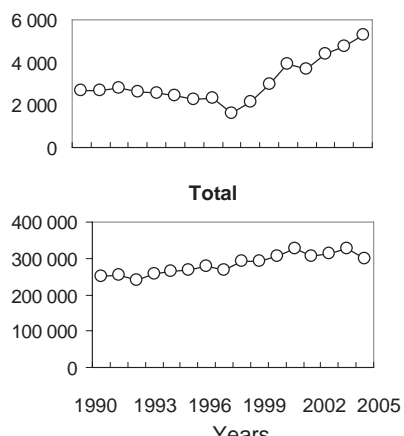

Years

Fig. 3. Potential consumption (in metric tons) of the nine species studied on the French market during the 1990-2005 period. Source: OFIMER (landings) and EUROSTAT (exports and imports).

species on the French market, as defined in the previous section (i.e. including trade data for different species that may be labelled with the same name in the trade databases). The Bay of Biscay landings represent $38 \%$ to $56 \%$ of domestic production for the nine species as a whole, and approximately $20 \%$ of potential consumption on the French market. Relationships between fishery production and potential consumption of the French market are indicated in terms of coverage rate (Table 1). Based on this analysis, only the landings of four species derived from the Bay of Biscay can be considered as making a significant contribution to the domestic market: anchovy, cuttlefish, seabass and sole, of which more than $29 \%$ of the total consumption is covered by the Bay of Biscay production.

The case of anchovy deserves special attention, because of the emergency measures taken to close the fishery in the Bay of Biscay in 2005 (Commission of the European Communities 2005). From 2003, the production of this species was less than $50 \%$ of the potential consumption for consumers and plants; it decreased to $9 \%$ in 2005 following the implementation of fishing restrictions. In previous years, the situation was radically different, with much higher coverage rates (maximum at $266 \%$ in 1990). The Biscay production of the other species (Nephrops, sardine, monkfish, hake and particularly pollack) weighted much less on the French market. This does not mean a low dependence of the market on domestic production, because marketing channels for fish products are segmented according to conditioning techniques (in particular with a difference between fresh and frozen products). Local production is mainly conditioned fresh for final uses on the domestic market, whereas frozen goods come principally from foreign countries and are used in the fish processing sector.

\section{Evolution of resources of the nine species on the French market}

Total resources for the nine species on the French market were computed from domestic production and trade flows. The evolution of three components of total resources is presented in Figure 4: Bay of Biscay production, landings from the other French fisheries, and foreign supply. Available quantities fluctuated around 300000 t from 1990 to 1997 and then increased to $3000 \mathrm{t}$ from 1998. At the same time, domestic contribution decreased from $40 \%$ to $30 \%$ of total resources, due exclusively to a sharp decline in landings from the Bay of Biscay fisheries (Fig. 4a). A similar trend was observed for value changes (Fig. 4b). Over the period, total resources in value maintained themselves at 800000 constant $€$ (2005), except during the fisheries crisis (see below) during which the total value of the resources available on the market dropped to 700000 constant $€$.

\section{Evolution of the price indices}

Over the study period, changes in markets for fish did indeed have a strong impact on the evolution of price index, particularly for Bay of Biscay production. In particular, the market crisis which occurred in France in the mid-1990s, led to a particularly sharp drop in the ex-vessel prices of the selected species (Fig. 5). At the national level, prices decreased by $31 \%$ between 1991 and 1994. The decrease was dramatically higher for Bay of Biscay production, with a drop by $72 \%$ in three years. Over the same time period, changes in the price index appeared quite limited for foreign trade $(-6 \%$ for exports and $-14 \%$ for imports). Following the crisis, import prices tended to increase from 1996 until 2001 and then decreased over the next three years. Ex-vessel prices rose between 2000 and 2005, reaching the same level as that observed in 1990 (in constant 2005 prices) at the end of the study period.

\section{Position of individual species in the multivariate analysis}

The first three axes of the MFA accounted for $79 \%$ of the total variance in the data. The high score (15.2) of the first Eigenvalue showed that the first MFA factor represents an important direction of variance for each of the years. The correlation coefficients between the first three MFA factors and the projection of each group of indicators (years) were higher than 0.75 , indicating that the structuring factors expressed by the first three principal components of the MFA were common to all years. 
Table 4. Significant linear trends observed in the abundance and mean weight of the nine selected species during the period 1987 to 2006 , from data collected during groundfish surveys carried out in autumn on the eastern continental shelf of the Bay of Biscay. Latitudinal categories are from Table 3.

\begin{tabular}{|c|c|c|c|c|}
\hline \multirow{2}{*}{ Species } & \multicolumn{2}{|c|}{ Trend in survey } & \multirow{2}{*}{$\begin{array}{l}\text { Latitudinal } \\
\text { category }\end{array}$} & \multirow{2}{*}{$\begin{array}{l}\text { Expected impact of } \\
\text { climate warming } \\
\text { on population abundance }\end{array}$} \\
\hline & Abundance & Mean weight & & \\
\hline Anchovy & $\Leftrightarrow$ & $\Leftrightarrow$ & 13 & positive \\
\hline $\begin{array}{l}\text { Monkfish } \\
\text { (L. budegassa) }\end{array}$ & $\diamond$ & $\Leftrightarrow$ & 13 & positive \\
\hline Nephrops & $\Leftrightarrow$ & $\Leftrightarrow$ & 23 & none \\
\hline Cuttlefish & $\diamond$ & $\Leftrightarrow$ & 22 & none \\
\hline Sole & $\Leftrightarrow$ & $\Leftrightarrow$ & 22 & none \\
\hline Seabass & $\curvearrowright$ & $\Leftrightarrow$ & 22 & none \\
\hline Sardine & 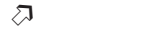 & $\Leftrightarrow$ & 22 & none \\
\hline Hake & $\Leftrightarrow$ & $\Leftrightarrow$ & 22 & none \\
\hline $\begin{array}{l}\text { Monkfish } \\
\text { (L. piscatorius) }\end{array}$ & $\diamond$ & 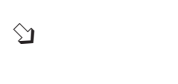 & 31 & negative \\
\hline Pollack & এ & $\Leftrightarrow$ & 31 & negative \\
\hline
\end{tabular}
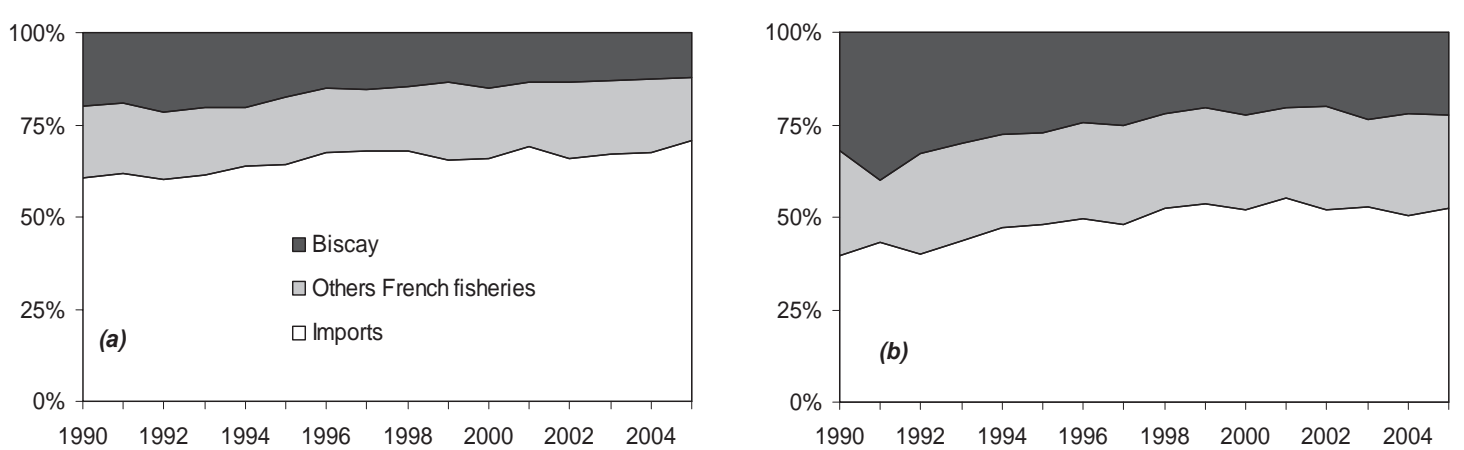

Fig. 4. Evolution of total resources of selected species on the French Market, in metric tons (a) and 2005 constant Euro (b), $1990-2005$.

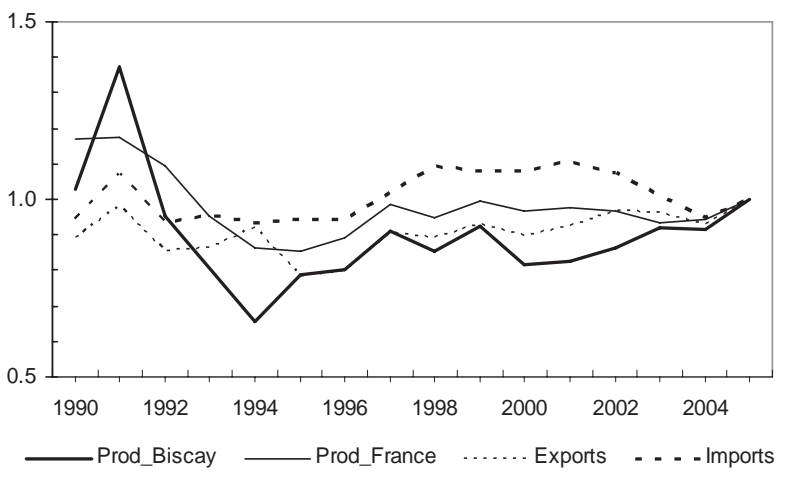

Fig. 5. Evolution of Fisher price index during the 1990-2005 period. Source: OFIMER (landings) and EUROSTAT (exports and imports).

The first three axes of the MFA provide a good representation of the main changes in the exploitation and marketing of the nine species over the studied period. The correlation between the indicators and the axes is summarized in Table 3. Potential consumption, and landings and volume of exported frozen products from the Bay of Biscay are positively correlated with axis 1 , whereas all price variables are negatively correlated with this axis. Potential consumption and volume of imported frozen products are positively correlated with axis 2, while Bay of Biscay landings and volume of exported fresh products are negatively correlated with this axis. Bay of Biscay landings and volume of imported fresh products are negatively correlated with axis 3 . Apart from potential consumption (correlated with axes 1 and 2) and Bay of Biscay landings (correlated with the three axes), most of the variables are more specifically correlated with just one axis.

The mean positions of species are displayed in Figure 6. The projection of individuals (species) reveals a strong inertia on the first axis. Two groups of species can be distinguished from their scores on axis 1. The first group, among which are Nephrops, monkfish, sole, and seabass, is characterized by high prices. Fresh imports of monkfish, sole and Nephrops were observed during the study period, while there was a strong increase in fresh seabass product imports. With respect to axis 1 , there was a strong demand for species of the second group (pollack, hake, sardine, cuttlefish and anchovy) which were landed from the Bay of Biscay and exported in the form of frozen products in large quantities. The demand for pollack, and to a lesser extent for hake, was particularly strong and seemed to correspond to large imports of frozen products. Landings of sardine, cuttlefish and anchovy from the Bay of Biscay were relatively large and associated with exports 


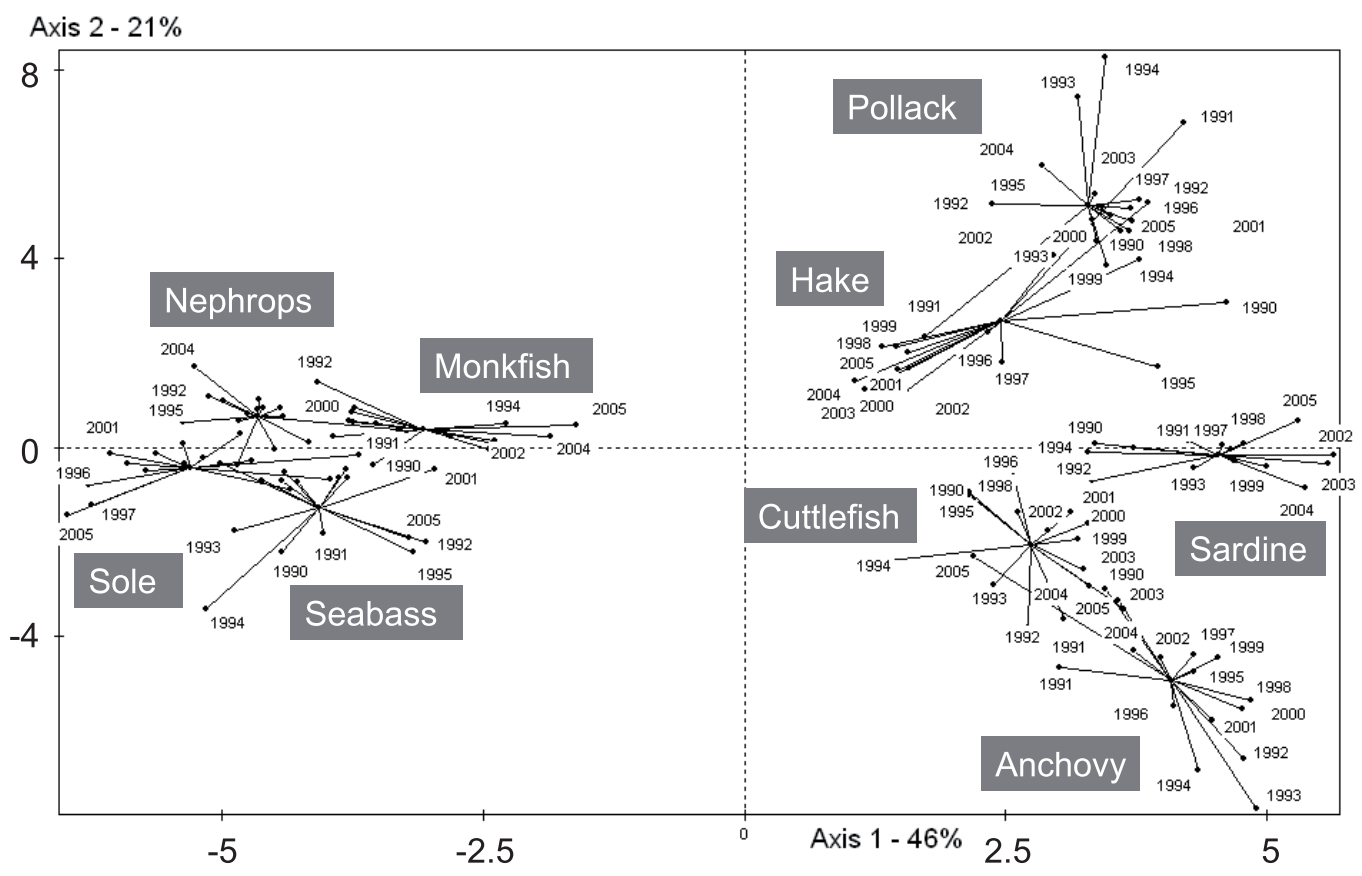

Fig. 6. Graphical depiction of the projections of the nine species on the principal multiple factor analysis plane. Diamonds represent the centres of gravity of the species observed over the 16 years. Symbol size is proportional to contribution of a species to the construction of the axes. Plus signs indicate the position of each species in the relevant year.

of fresh products. The year-to-year variability by species (i.e., the distribution of the years around each species in Fig. 6) was higher for hake, pollack, sole, anchovy and cuttlefish than for other species.

The position of the years in the principal plane of the MFA is explained by the correlation between the axes and the variables (Table 3). All years are strongly linked with the first axis (price and quantity relationships), although the two first years and the last are less well correlated. In contrast, axis 2 separated the years 1992, 1993, 1994 from others. These years displayed relatively high correlation coefficients, between 0.6 and 0.7 . They were characterized by high values for potential consumption and the volume of imported frozen products, together with low landings from Bay of Biscay and low volume of exported fresh products.

\section{Discussion}

While a growing number of studies demonstrate the effects of global climate change on fisheries at a worldwide level (Schrank 2003) and recommend engaging similar studies at regional scales, the challenge is to include an economic perspective in this evaluation, considering both domestic and foreign production. One of the main anticipated effects of climate change is a modification in the composition of exploited fish communities. The economic implications of such changes will depend on the market position of fish production derived from these communities, and on the associated responses of prices to variations in volumes landed, which may differ between species. The results presented in the previous section provide some insights into the potential implications of climate change for fisheries, targeting the nine selected species in the Bay of Biscay. Assessing the global economic stakes of climate-induced
changes in the fish community

Climate-induced changes in the fish community of the eastern continental shelf of the Bay of Biscay were identified by Poulard and Blanchard (2005). Species having a northerly distribution and a narrow latitude distribution range exhibited declining trends of their abundance and biomass. On the other hand, species exhibiting a trend of increasing abundance indices were characterized by a southern distribution and a wide latitude range. It was not however possible to clearly separate the relative role of fishing impacts and climate-induced changes on the community. For the two Boreal species in our analysis, i.e. monkfish (L. piscatorius) and pollack, a negative effect of climatic warming might be expected. In this case, negative effects of fishing and climate-induced changes would be cumulative. For anchovy, a positive response to warming conditions could potentially be expected. However, in the Bay of Biscay the exploitation of anchovy depends to a large extent on yearly recruitment success. This recruitment is driven by mesoscale ocean processes (Allain et al. 2001) related to meteorological regimes. Exploitation of anchovy in the Bay of Biscay might thus be largely affected by changes in these regimes induced by global warming. In the same way, potential positive effects of warming on monkfish (L. budegassa) might be reduced by the high intrinsic vulnerability of this species to fishing (Cheung et al. 2007) due to its rather large body size. 
Even if, based on the sensitivity index calculated above, we assume a positive potential impact of climate change on anchovy (Engraulis encrasicolus) and a negative potential impact on pollack (Pollachius pollachius) and monkfish (Lophius piscatorius), we come to the conclusion that a major part (69\% to $87 \%$ ) of the gross turnover associated with catches of the selected fish species in the Bay of Biscay remains potentially unaffected by long-term changes related to climate. Only 6 to $17 \%$ of this production could be potentially negatively affected by climate change (in relation to fisheries for Pollachius pollachius and Lophius piscatorius).

\section{Economic implications of modifications in the composition of landings}

The analysis presented in the previous section shows that the structure of fisheries production by French fleets operating in the Bay of Biscay has markedly changed over the years of this study. Based on these results, and on the typology of fish species derived from the multi-factorial analysis, we can assess the economic implications of such changes.

Results derived from the AFM clearly separate two groups of species, the first characterized by higher prices, and the second by larger volumes available on the French market. The position of the first group of species (Nephrops, monkfish, seabass and sole) on the market, as described by the multifactorial analysis, remained relatively stable throughout the study period. Landings of these species are destined mainly for the French fresh fish market, and face limited competition from imports of fresh products. Indeed, as illustrated by the case of Nephrops, large imports of these species are mainly for frozen products with only limited potential interactions with the market for fresh products. The second group of five species (anchovy, cuttlefish, sardine, hake and pollack), characterised by lower price levels, saw greater fluctuations in the position of the individual species on the French market. Price responses to variations in landed volumes appeared to be much higher than for the first group, as is illustrated by prices of hake in 1990, pollack in 1991, cuttlefish in 1994 or anchovy in 2005. Landings of these species are destined both for the French market, on which large volumes of imported frozen products also exist (with questions as to whether these imports interact with the market for local products), and for the export market.

Species with higher prices are marketed mainly on the domestic fresh market, and appear to face a limited number of substitutes. This group of products displays less price flexibility, and demand appears to be relatively inelastic, which is characteristic of goods belonging to the luxury class. For these species, one can thus expect that even as ex-vessel prices rise, demand will not decrease, and supply may increase (Hutchinson et al. 2001), though in a "backward-bending" fashion (Copes 1970). In contrast, demand for species with lower prices, which arrive on markets where they may have many substitutes, will tend to decrease with higher prices; leading supply to stabilize or even decrease if prices remain too low compared with harvesting costs. Hence, under open access conditions, the economic implications of changes in the composition of landings by fleets operating in the Bay of Biscay, as illustrated in this article and that by Steinmetz et al. (2008), will be directly related to the position of the landed species on the market. For fishing fleets producing mainly high price products, the potential impacts of changes in landings will be related to the so-called "backward-bending supply curve" (Copes 1970), indicating that beyond the maximum sustainable yield of individual species, prices can continue to rise while output is decreasing. Changes in catch rates which may result from changes in the environmental conditions of the stocks (e.g. lower catch rates due to unfavourable environmental conditions) will accentuate this process. For fleets dependent on lower price products, changes in catch rates will be amplified via the price variations and adjustments of demand and supply, hence greater levels of variability may be expected in the gross turnover associated with the landings of these species.

The results presented here provide a basis for further exploration of the implications of the market position of fish species for the analysis of the economic consequences of composition changes in fishery landings. Future research on this issue will need to focus more specifically on the determinants of price differences and price formation for the different groups of species considered in the analysis.

Acknowledgements. This research is part of the on-going CHALOUPE project: Global change, dynamics of exploited marine biodiversity, and viability of fisheries - Biodiversity project ANR-IFB 2005 (http://www.projet-chaloupe.fr).

\section{References}

Allain G., Petitgas P., Lazure P., 2001, The influence of mesoscale ocean processes on anchovy (Engraulis encrasicolus) recruitment in the Bay of Biscay estimated with a three-dimensional hydrodynamic mode. Fish. Oceanogr. 10, 151-163.

Blanchard F., Vandermeirsch F., 2005, Warming and exponential abundance increase of the subtropical fish Capros aper in the Bay of Biscay (1973-2002). C. R. Biol. 328, 505-509.

Castro-Ortiz J.L., Luch-Belda D. 2007, Low frequency variability of fishing resources, climate, and ocean. Fish. Res. 85, 186-196.

Cheung W.W., Watson R., Morato T., Pitcher T.J., Pauly D., 2007, Intrinsic vulnerability in the global fish catch. Mar. Ecol. Prog. Ser. 333, 1-12.

Commission of the European Communities. 2005, Commission regulation (EC) No1037/2005 of 1st July 2005 establishing emergency measures for the protection and recovery of the anchovy stock in ICES Sub-area VIII.

Copes P., 1970. The backward-bending supply curve of the fishing industry. Scott. J. Political Econ. 17, 69-77.

Désaunay Y., Guérault D., Le Pape O., Poulard J.-C. 2006, Changes in occurrence and abundance of northern / southern flatfishes over a 20-year period in a coastal nursery area (Bay of Vilaine) and on the eastern continental shelf of the Bay of Biscay. Sci. Mar. 70S1, 193-200.

Escofier B., Pagès J. 1994, Multiple factor analysis (AFMULT package). Comput. Stat. Data Anal. 18, 121-140.

Hiddink J.G., Ter Hofstede R., 2008, Climate induced increases in species richness of marine fishes Global Change Biol. 14, 453460. 
Hutchinson S.D., Larkin S.L., Lee D.J., Adams C.M., Milon J.W., 2001, Policy implications ofd restricted access strategies for multispecies fisheries. Annual Meeting Am. Agric. Econ. Assoc. Chicago, $23 \mathrm{p}$.

Koutsikopoulos C., Beillois P., Leroy C., Taillefer F., 1998. Temporal trends and spatial structures of the sea surface temperature in the Bay of Biscay. Oceanol. Acta 21, 335-344.

Pauly D., Christensen V., Dalsgaard J., Froese R., Torres F., 1998, Fishing down marine food webs. Science 279, 860-863.

Perry A.L., Low P.J., Ellis J.R., Reynolds J.D. 2005, Climate change and distribution shifts in marine fishes. Science 308, 1912-1915.

Pinnegar J.K., Jennings S., O’Brien C.M. , Polunin N.V.C. 2002, Long-term changes in the trophic level of the Celtic Sea fish community and fish market price distribution. J. Appl. Ecol. 39, $377-$ 390.

Planque B., Beillois P., Jégou A.-M., Lazure P., Petitgas P., Puillat I., 2003, Large-scale hydroclimatic variability in the Bay of Biscay: the 1990s in the context of interdecadal changes. ICES Mar. Sci. Symp. 219, 61-70.

Poulard J.-C., Blanchard F., 2005, The impact of climate change on the fish community structure of the eastern continental shelf of the Bay of Biscay. ICES J. Mar. Sci. 62, 1436-1443.

Poulard J.C., Léauté J.P., 2002, Interaction between marine populations and fishing activities : temporal patterns of landings of
La Rochelle trawlers in the Bay of Biscay. Aquat. Living Resour. 15, 197-210.

Samuelson P.A., Nordhaus W.D., 2001, Economics. McGraw-Hill Higher Education, $17^{\text {th }}$ edn.

Schrank W.E., 2007, The ACIA, climate change and fisheries. Mar. Policy 31, 5-18.

Stanimirova I., Walczak B., Massart D.L., 2005, Multiple factor analysis in environmental chemistry. Anal. Chim. Acta, 545, 1-12.

Steinmetz F., Thébaud O., Blanchard F., Le Floc'h P., Bihel J., 2008, A bio-economic analysis of long term changes in the fisheries production of the Bay of Biscay. Aquat. Living Resour. 21, 317.

Steinmetz F., Thébaud O., Guyader O., Blanchard F., 2006, A preliminary analysis of long-term changes in the value of landings by French fishing fleets operating in the North-East Atlantic. IIFET Conference, Portsmouth (UK), Proceedings.

Stenevik E., Sundby S., 2007. Impacts of climate change on commercial fish stocks in Norwegian waters. Mar. Policy 31, 19-31.

Temam D., 2000. La nouvelle comptabilité nationale. Dunod, Paris.

Woillez M., Poulard J.-C., Rivoirard J., Petitgas P., Bez N., 2007. Indices for capturing spatial patterns and their evolution in time, with application to European hake (Merluccius merluccius) in the Bay of Biscay. ICES J. Mar. Sci. 64, 537-550. 